\title{
新课程背景下的小学教育教学管理分析
}

丁朝辉

武汉市黄陂区武湖红村小学

DOI:10.32629/jief.v2i5.1485

[摘 要] 随着我国新课程改革的不断深入, 我国小学教育教学管理理念不断发生变化。为了满足新课改要求, 教师要不断探索和研究教育教 学管理方式, 促进教育教学管理顺利进行。目前我国部分教师仍然在使用传统的、落后的管理方式和方法, 不能实现真正意义上的改革和管 理, 阻碍了学生综合素质的提升。

[关键词] 新课程背景下; 小学教育; 教学管理; 具体分析

中图分类号: G623.2 文献标识码: A

在素质教育背景下, 我国小学教育教学要严格按照新课改的要求进 行, 不断提升学生的综合素质, 促进学生健康发展。为此, 小学教师要 积极转变教育理念, 不断改进教学方法, 以小学生实际的学习情况制定 全新的小学教育教学管理思路, 充分利用各种教学资源, 真正贯彻和落 实新课程教学改革。

\section{1 我国小学教育教学管理中存在的问题}

1.1 教学理念落后

在新课程改革背景下, 我国部分小学教师仍然在使用传统的教育教 学管理模式, 没有更新教育理念, 树立学生课堂学习主体地位。同时教 师使用的评估方法、日常行为规范都没有跟上时代发展的潮流。很多学 校将学生学习成绩高低作为衡量教师工作水平的重要标杆, 没有严格按 照新课改的要求进行教学改革。

1.2 小学教育教学管理目标不明确

在新课改背景下, 我国相关教育者对于小学教育教学管理提出了自 己的想法和见解, 并且不断探索和研究教育教学管理方法。但是如果小 学教师在教育教学管理中不能制定明确的教学目标, 那么创造出的多种 多样的教学方法将会毫无意义, 在一定程度上降低小学教育教学质量和 教学效率。

\section{2 新课程背景下小学教育教学管理策略}

2.1 树立正确的小学教育教学理念

我国小学教育教学管理方式直接受到教育理念的影响。为此, 小学 教师在实际教学中要坚持以学生为本的教育理念, 防止以提高学生学习 成绩为出发点和落脚点进行教学。在新课程背景下, 小学教师要加强对 学生的素质教育, 保证使用的教学方法、教学理念紧跟时代发展步伐, 不断更新教学观念, 积极探索全新的、科学的教学方法。学校则要满足 素质教育的需求, 不断改进和调整教育观念, 鼓励教师在实际教学中充 分发挥自身的主观能动性, 积极参与到学校相关事务的处理和探讨中。 学校要让小学教师深刻的感受到学校管理人员对于教师的高度重视和关 心, 在学校处理各种事务时鼓励教师发表自己的想法和观点, 制定科学 合理的解决方案。学校要树立教师主人翁意识, 鼓励教师将学校作为自 己的家, 不断提升管理质量和管理效率。促使教师将更多的时间和精力 投入到教学中, 提高教育教学质量和教学效率, 有效解决实际教学中遇 到的问题。

\section{2 提高教师的管理水平}

在新课程背景下, 传统的教育管理方式已经无法满足学生的学习需 求和教师的教学需求。为了顺应时代发展, 小学教师要树立科学的、先 进的教育观念, 不断提升自身综合素养和专业水平, 增强教学能力。为
此学校要定期开展教师培训活动, 向教育管理者传授科学的教育理念和 正确的教育方法, 不断提升管理者的专业技能。同时, 学校要以自身发 展情况为基础, 不断改良新型的管理方式, 坚持因地制宜, 防止在管理 中出现不认真、随意的现象。聘请专业的管理人员开展管理工作, 制定 科学的管理方法。

除此之外, 学校要定期组织管理活动, 让教育管理者共同分析、研 究、探讨各种管理问题。学校要重视管理人员综合素质的提升, 提升教 师的管理水平, 做好班级管理、教学管理等多个方面的工作。

2.3 明确教学目标

在实际的教育教学中, 小学教师需要明确教学目标。学校管理人员 要从教师的角度出发, 制定正确的管理理念, 有效解决教师在教学中遇 到的问题。制定完善的管理计划和方案, 鼓励教师制定适合学生发展的 教育方法, 提升小学教育教学效果和质量。同时教师要加强与学校的合 作和交流, 共同完成教育教学管理目标, 鼓励教师在实际教学中积极的 反思和思考, 审视自己工作中存在的问题, 制定科学的措施有效的解决 问题。

\section{4 建立完善的考核体系}

在传统的小学教育教学中, 只是将学生学习成绩作为考核和评价教 师工作水平的唯一标准, 这阻碍了教师工作顺利进行。在新课程背景下, 教师要重点培养学生的综合素养, 制定科学、完善的考核体系。同时在 管理人员的指导下小学教育教师要顺应教育的发展, 全面提升学生的综 合素养。在制定考核标准过程中, 要使用全方位、多方面的评价方式, 鼓励学生和学校管理人员共同参与教师的评价工作中, 准确的找出教师 在教学中存在的不足之处, 鼓励教师有效解决问题, 确定教学目标。这 种完善的考核体系可以充分调动教师工作的主动性和积极性, 使教师制 定阶段性、合理的教学目标, 促进小学教育教学管理工作顺利进行。

\section{3 结语}

在新课程背景下, 小学教育教学管理工作要顺应教育发展, 不断调 整管理方式, 制定完善的管理体系。同时学校要根据实际发展情况制定 科学的教学教育管理计划, 全面提升教师的综合能力和水平。

\section{[参考文献]}

[1]席卫权.新课程背景下小学教育教学管理方法的创新分析[J]. 大 陆桥视野,2018(14):270-270.

[2]何彦霞.新课程改革背景下小学教学管理中存在的问题与对策研 究[J].教育教学论坛,2019(19):16-16.

[3] 宋喜民. 浅谈新课程背景下的小学教育教学管理 [J].2019(11):88-88. 